\title{
Oils rich in alpha linolenic acid: chemical composition of perilla (Perilla frutescens) seed oil ${ }^{\text {th }}$
}

\author{
Paolo Bondioli ${ }^{1, *}$, Liliana Folegatti ${ }^{2}$ and Pierangela Rovellini ${ }^{2}$ \\ ${ }^{1}$ Freelance expert, Milano, Italy \\ 2 INNOVHUB-SSI-SSOG, Milano, Italy
}

Received 13 September 2020 - Accepted 9 November 2020

\begin{abstract}
In this paper, the main chemical properties of Perilla seed oil (PO) obtained by mechanical pressing of Perilla seeds are reported. The analysis of fatty acid composition has highlighted a very high amount of (n-3) $\alpha$-linolenic acid (ALA), more than 60\%, higher than other ALA rich oils such as linseed and sacha inchi oils and similar to chia oil. PO has an important sterol (higher than $3000 \mathrm{mg} / \mathrm{kg}$ ) and vitamin E (approx. $870 \mathrm{mg} / \mathrm{kg}$ ) content, while biophenols are in quite low concentration. The analyzed sample showed a very low acid and peroxide value and this is the demonstration that, following the proper technological procedures, it is possible to obtain high quality oils even in presence of high $\alpha$-linolenic acid concentrations.
\end{abstract}

Keywords: Perilla frutescens / oil composition / omega 3 fatty acids / tocopherols

Résumé - Huiles riches en acide alpha-linolénique : composition chimique de l'huile de graines de Perilla frutescens. Cet article présente les principales propriétés chimiques de l'huile de graines de Perilla (PO) obtenue par pression mécanique de graines de Perilla frutescens. L'analyse de la composition en acides gras a mis en évidence une quantité très élevée d'acide (n-3) $\alpha$-linolénique (ALA), plus de $60 \%$ supérieure à celle d'autres huiles riches en ALA telles que les huiles de lin et de sacha inchi et similaire à l'huile de chia. L'huile PO offre une teneur importante en stérols (supérieure à $3000 \mathrm{mg} / \mathrm{kg}$ ) et en vitamine $\mathrm{E}$ (environ $870 \mathrm{mg} / \mathrm{kg}$ ), tandis que les biophénols sont en concentration assez faible. L'échantillon analysé a montré un indice d'acidité et de peroxyde très faible. Cela démontre que, selon les procédures technologiques appropriées, il est possible d'obtenir des huiles de haute qualité même en présence de concentrations élevées en acide $\alpha$-linolénique.

Mots clés : Perilla frutescens / composition de l'huile / acides gras oméga 3 / tocophérols

\section{Introduction}

Uncommon oils rich in alpha linolenic acid have several interesting properties, as demonstrated during some previous studies (Bondioli, 2006; Bondioli et al., 2006; Bondioli, 2019).

Perilla frutescens is an annual aromatic plant belonging to the Lamiaceae family, also known in Japan as egoma or shiso. It is the only species belonging to the genus Perilla and it is widespread in India, Vietnam, Korea, China and Japan.

Both leaves and the oil obtained from the seeds are used for culinary and medical purposes (Yu et al., 1997). Perilla seed oil (PO), on the other hand, can be used as a salad oil or for industrial applications such as paints, dyes and inks.
$\mathrm{PO}$ is not an absolute novelty for Italian market, because after the Second World War, in the North of Italy, some facilities for seed crushing and oil refining were installed. At that time, the oil was in use as a drying oil for paints preparation. In fact, some information about its composition can be found in a technical manual distributed until 1988 in Italy by a supplier of oil plants for oil extraction and refining (Agenda Gianazza, 1988). From this source, we can get iodine value (190-208 $\left.\mathrm{g} \mathrm{J}_{2} / 100 \mathrm{~g}\right)$, saponification value $(180-197 \mathrm{mg} \mathrm{KOH} / \mathrm{g})$, melting point $\left(-14 /-18^{\circ} \mathrm{C}\right)$, refractive index $\left(1.4800-1.4820\right.$ at $\left.20^{\circ} \mathrm{C}\right)$. The seed contains $41-45 \%$ of oil. The reported fatty acid composition is palmitic 5-8\%, palmitoleic $0.5 \%$, stearic $5-8 \%$, oleic $4-10 \%$, linoleic $34-$ $44 \%$, linolenic $44-49 \%$.

\footnotetext{
"Contribution to the Topical Issue "Minor oils from atypical plant sources / Huiles mineures de sources végétales atypiques"

*Corresponding author: paolo.bondioli1956@gmail.com
} 
More recently, some researchers investigated the impact of physical pretreatments on the quality of extracted PO (Sirilun et al., 2016), while others studied the possibility to carry out an aqueous enzyme-assisted process for oil recovery (Li et al., 2014).

During our research, we received a sample of PO for other studies about the preparation of a balanced blend (under the point of view of fatty acid composition), elsewhere published (Torri et al., 2019) and we took the opportunity to carry out a very detailed study on the composition of this interesting vegetable oil.

From the nutritional standpoint, an interest for this vegetable oil stands in its high concentration of $\alpha$-linolenic acid (approximately 60\%) and in the possibility to use it as an integrator contributing to re-balance the fatty acids $\omega 6 / \omega 3$ ratio, strongly altered in the Western diet. In fact, our actual lipid nutrition is strongly oriented towards $\omega 6$ fatty acids, with a very low amount of $\omega 3$. The reason for this comes from their high tendency to oxidation and therefore in the practice to obtain processed food low in $\alpha$-linolenic acid.

Nowadays, only soy and rapeseed oils, among the common commercial oils contain up to $10 \%$ of $\alpha$-linolenic acid. For this reason, it is suggested to integrate the lipid profile using other oilseeds, such as linseed (Linum usitatissimum), sacha inchi (Plukenetia volubilis), walnut (Juglans regia), hemp (Cannabis sativa), camelina (Camelina sativa) and chia (Salvia hispanica).

In this paper, we describe the fatty acid composition of Perilla oil compared to other linolenic acid rich oils, like linseed, sacha inchi and chia: we also report the sterol and tocopherol composition, together with other relevant chemical parameters of PO.

\section{Material and methods}

\subsection{Materials}

Perilla seed oil was obtained from a Japanese factory located in Toyama prefecture. The oil was prepared by simple mechanical pressing using a hydraulic press operating batch wise at ambient temperature, without previous heating, with a seed load of approximately $2 \mathrm{~kg}$ of seed for each batch. The maximum operating pressure was $400 \mathrm{~kg} / \mathrm{cm}^{2}$ and the oil was filtered immediately after extraction to obtain a limpid product to be stored in dark containers.

We received a sample of this oil freshly prepared for our research.

\subsection{Analytical methods}

- Free fatty acids were determined by means of volumetric titration using phenolphthalein as an indicator using UNI EN ISO 660:2009 standard method.

- Peroxide value was determined by means of volumetric titration based on the liberation of iodine from potassium iodide in presence of hydroperoxides. A starch aqueous solution was used as an indicator according to UNI EN ISO 3960:2010.

- UV/Vis absorption: samples were dissolved in isooctane ( $1 \%$ concentration) and spectrophotometrically evaluated in the UV wavelength range using a cell having an optical path of $1 \mathrm{~cm}$. The extinction coefficients were calculated respectively for the absorption at 232 and $270 \mathrm{~nm}$, according to ISO 3656:2011.

- Fatty acid composition was determined according to ISO 12966-2:2017 + ISO 12966-4:2015. The analyses were carried out by a gas-chromatograph FOCUS (Thermoquest Instrument, Rodano, Italy) equipped with a flame ionization detector (GC-FID), using a capillary column (CP-Sil $88-1=100 \mathrm{~m}, \quad 0.32 \mathrm{~mm}$ ID, film thickness $0.25 \mu \mathrm{m}$; Supelco, Bellefonte, PA, USA) after derivatization of fatty acids into the corresponding methyl esters, under the following experimental conditions: carrier gas He at a flow rate of $1.5 \mathrm{~mL} / \mathrm{min}$; split injection system with a splitting ratio 1:40; injector and detector temperatures set at 250 and $260^{\circ} \mathrm{C}$ respectively; using the following program: 90 $240{ }^{\circ} \mathrm{C}$ at $7^{\circ} \mathrm{C} / \mathrm{min}$; injected quantity $1 \mu \mathrm{L}$.

- Sterol content and composition: the procedure, according to NGD 71-1989 + NGD 72-1989, is based on saponification, recovery of unsaponifiable fraction, purification of sterol fraction by preparative TLC, recovery and TMS derivatisation of the sterol, GC-FID evaluation by means of an internal standard ( $\alpha$-cholestanol). The sterol composition was determined using a gas-chromatograph TRACE (Thermoquest Instrument, Rodano, MI, Italy) equipped with a flame ionization detector. Analysis was carried out with a CPSil 8CB (Supelco, Bellefonte, PA, USA) capillary column $(1=30 \mathrm{~m}, 0.32 \mathrm{~mm}$ ID, film thickness $0.25 \mu \mathrm{m})$ under the following conditions: carrier gas He at a flow rate of $1.5 \mathrm{~mL} / \mathrm{min}$; split injection system with a splitting ratio 1:50; injector and detector temperatures set at 250 and $260^{\circ} \mathrm{C}$, respectively; oven isothermal temperature set at $240{ }^{\circ} \mathrm{C}$; injected quantity $1 \mu \mathrm{L}$.

- Unsaponifiable matter, according to ISO 3956:2000: samples were treated with alcoholic $\mathrm{KOH}$ solution and the unsaponifiable matter was obtained by means of liquidliquid extraction using diethyl ether. The quantification of unsaponifiable material was carried out gravimetrically.

- Tocopherols were evaluated according to ISO 9936:2016. A sample amount is simply diluted in hexane and injected in a HPLC system operating in direct phase with a silica column $4.6 \mathrm{~mm}$ ID $\times 250 \mathrm{~mm}$ length (Hypersil, Thermofisher, Rodano, Italy) using a mixture of hexane $99.5 \%$ and isopropanol $0.5 \%$ as isocratic eluting system with a flow rate of $1.0 \mathrm{~mL} / \mathrm{min}$. The injection volume was $10 \mu \mathrm{L}$ for both sample and standard. Detection is carried out by means of a fluorescence detector (excitation wavelength $290 \mathrm{~nm}$, emission wavelength $330 \mathrm{~nm}$ ) and quantification is obtained by means of external standardisation with mixture of single tocopherols forms preparing different calibration levels. Reference tocopherols were obtained from Sigma Aldrich, Italy.

- Oxidation stability (Rancimat test, ISO 6886:2006): to determine the oxidation stability an accelerated oxidation test was performed. Oxidation induction times were measured by a Rancimat apparatus model 743 (Metrohm, Herisau, CH) using ISO 6886:2006 standard on $3 \mathrm{~g}$ of oil heated at $110^{\circ} \mathrm{C}$, under a purified air flow of air flow of $10 \mathrm{~L} / \mathrm{h}$.

- Biophenols (internal method based on COI T20 Doc. 29 2009 method). Biophenols were extracted from oil $(2 \mathrm{~g})$ using a solution of methanol/water $80 / 20 \mathrm{v} / \mathrm{v}(5 \mathrm{~mL})$ and analysed by HPLC-PDA injecting $20 \mu \mathrm{L}$ in the analytical 
Table 1. Fatty acid composition of Perilla oil and of two different $\omega 3$ rich vegetable oils (average values of two independent replicates \pm expanded uncertainty of measurement).

\begin{tabular}{|c|c|c|c|c|c|}
\hline & Unit & Perilla oil ${ }^{*}$ & $\begin{array}{l}\text { Linseed oil } \\
\text { (Bondioli, 2006) }\end{array}$ & $\begin{array}{l}\text { Sacha inchi oil } \\
\text { (Bondioli et al., 2006) }\end{array}$ & $\begin{array}{l}\text { Chia oil } \\
\text { (Rodriguez et al., 2020) }\end{array}$ \\
\hline $\mathrm{C} 14: 0$ & $\%$ & $0.02 \pm 0.01$ & 0.04 & - & - \\
\hline C16:1 & $\%$ & $0.12 \pm 0.05$ & 0.10 & 0.06 & - \\
\hline $\mathrm{C} 17: 0$ & $\%$ & $0.03 \pm 0.01$ & - & - & - \\
\hline C17:1 & $\%$ & $0.03 \pm 0.02$ & - & - & - \\
\hline C18:1 & $\%$ & $12.61 \pm 0.66$ & 23.42 & 8.77 & 7.55 \\
\hline C18:2 & $\%$ & $18.30 \pm 0.21$ & 13.56 & 33.67 & 19.18 \\
\hline C18:3 & $\%$ & $59.87 \pm 0.05$ & 52.13 & 50.73 & 63.49 \\
\hline $\mathrm{C} 20: 0$ & $\%$ & $0.11 \pm 0.07$ & 0.12 & 0.07 & - \\
\hline $\mathrm{C} 20: 1$ & $\%$ & $0.13 \pm 0.05$ & - & 0.26 & - \\
\hline $\mathrm{C} 22: 0$ & $\%$ & $0.02 \pm 0.02$ & 0.21 & - & - \\
\hline
\end{tabular}

* Average value of two independent replicates \pm expanded uncertainty of measurement.

system at flow $1.0 \mathrm{~mL} / \mathrm{min}$. The analysis was performed using a gradient composed by water containing $0.2 \%$ $\mathrm{H}_{3} \mathrm{PO}_{4}(\mathrm{v} / \mathrm{v})$, methanol and acetonitrile with a composition able to resolve most of the peaks present. A reverse phase column was used (Alltima-Grace, Italy $250 \mathrm{~mm}$ length $\times 4.6 \mathrm{~mm}$ ID, particle size $5 \mu \mathrm{m}$ ). The chromatogram was recorded at $280 \mathrm{~nm}$ and the quantitative content was reported as $\mathrm{mg} / \mathrm{kg}$ of tyrosol for comparison with olive oil.

All tests were carried out in duplicate under repeatability conditions.

\section{Results and discussion}

In Table 1, the fatty acid composition of Perilla frutescens oil is reported, in comparison with some of the possible competitors, linseed, sacha inchi and chia oils.

Looking at fatty acid composition we can say that PO contains the highest concentration of $\alpha$-linolenic acid, if compared with linseed or sacha inchi oils, very close to the one of chia oil (Rodriguez et al., 2020), with a ratio between $\omega 6$ and $\omega 3$ fatty acids of 0.30 . From the nutritional standpoint, ratios between 5 and 10 are recommended as optimal for human health (WHO Interim Summary, 2008). So, the value of 0.30 is quite far from the optimal one, but the use of $\mathrm{PO}$ for culinary or integration purposes could represent a way to contribute to re-equilibrate the ratio $\omega 6 / \omega 3$ in the diet. Common vegetable oils such as olive, sunflower, corn, peanut, palm, are characterized by very high $\omega 6 / \omega 3$ ratios, higher than the nutritionally optimal value. If we consider classical vegetable oils in use for human consumption only soybean and rapeseed oil demonstrate a correct $\omega 6 / \omega 3$ ratio. However, all linolenic acid rich oils cannot be regarded as a substitute of (n-3) acids from fish oils such as eicosapentaenoic acid (EPA) and docosahexaenoic acid (DHA), but a very important complement (Cassiday, 2017; Stanley, 2009).
Table 2. Total sterol content $(\mathrm{mg} / \mathrm{kg})$ and composition (\%) of Perilla oil average values of two independent replicates \pm expanded uncertainty of measurement).

\begin{tabular}{ll}
\hline Sterol & Perilla oil \\
\hline Cholesterol (\%) & $0.15 \pm 0.12$ \\
Brassicasterol (\%) & $<0.01$ \\
24 Methylene Cholesterol (\%) & $0.51 \pm 0.06$ \\
Campesterol (\%) & $7.02 \pm 0.65$ \\
Campestanol (\%) & $0.15 \pm 0.10$ \\
Stigmasterol (\%) & $3.30 \pm 0.34$ \\
Delta 7 Campesterol (\%) & $0.71 \pm 0.11$ \\
Delta 5, 23 Stigmastadienol (\%) & $<0.01$ \\
Clerosterol (\%) & $0.61 \pm 0.29$ \\
Beta Sitosterol (\%) & $69.70 \pm 2.84$ \\
Sitostanol (\%) & $0.66 \pm 0.94$ \\
Delta 5 Avenasterol (\%) & $8.47 \pm 1.32$ \\
Delta 5, 24 Stigmastadienol (\%) & $1.61 \pm 0.75$ \\
Delta 7 Stigmastenol (\%) & $3.01 \pm 0.32$ \\
Delta 7 Avenasterol (\%) & $4.10 \pm 0.47$ \\
Total sterols (mg/kg) & $3260 \pm 459$ \\
\hline
\end{tabular}

Like in all vegetable oils, the sterol composition is peculiar to each botanical family and in the case of Perilla frutescens is reported in Table 2. The most abundant sterol in PO sterol fraction is represented by beta-sitosterol, with important amounts of campesterol, delta 5 and delta 7 avenasterol, delta 7 stigmastenol. Very interesting is the high total sterol content that exceeds $3000 \mathrm{mg} / \mathrm{kg}$. It is well known that phytosterols counteract cholesterol adsorption at intestinal level and this could represent an additional reason for the food use of this highly unsaturated oil.

The main chemical properties of the evaluated sample, representing a simply cold pressed and filtered oil, are resumed in Table 3. 
Table 3. Main chemical properties of Perilla oil (average values of two independent replicates \pm expanded uncertainty of measurement).

\begin{tabular}{ll}
\hline Parameter & Perilla oil \\
\hline Free fatty acids (\% oleic acid) & $0.37 \pm 0.03$ \\
Peroxide value $(\mathrm{meqO} / \mathrm{kg})$ & $5.4 \pm 0.9$ \\
UV absorption $\mathrm{K}_{232}(\mathrm{ABS}$ units) & $1.682 \pm 0.093$ \\
UV absorption $\mathrm{K}_{270}(\mathrm{ABS}$ units) & $0.123 \pm 0.021$ \\
UV absorption Delta K (ABS units) & $0.005 \pm 0.006$ \\
Unsaponifiable $(\%)$ & $0.60 \pm 0.44$ \\
Total sterols $(\mathrm{mg} / \mathrm{kg})$ & $3260 \pm 459$ \\
Total biophenols $(\mathrm{mg} / \mathrm{kg})$ & $45 \pm 16$ \\
Rancimat induction time at $110^{\circ} \mathrm{C}$ (hours) & $<1.0$ \\
\hline
\end{tabular}

Table 4. Tocopherol content $(\mathrm{mg} / \mathrm{kg}$ ) of PO (average values of two independent replicates \pm expanded uncertainty of measurement, for total tocopherols only).

\begin{tabular}{ll}
\hline Tocopherol & Perilla oil \\
\hline Alpha & 23 \\
Beta & 2 \\
Gamma & 831 \\
Delta & 14 \\
Total tocopherols & $870 \pm 16$ \\
Total tocotrienols & $<1$ \\
\hline
\end{tabular}

We can observe that the sample was in good hydrolytic and oxidative conditions, as confirmed by the UV absorption data. Unsaponifiable and total sterols contents are in good agreement, while only few $\mathrm{mg} / \mathrm{kg}$ of biophenols have been detected. The oxidation stability, as evaluated by means of Rancimat, is very low, because of the presence of high concentration of di- and triunsaturated fatty acids.

In Table 4, the results of tocopherols analysis are reported. The total content demonstrates that Perilla oil could represent a good source of vitamin $\mathrm{E}$ with a level similar to sunflower oils.

In practice, gamma-tocopherol represents more than $95 \%$ of this fraction, the remaining amount being covered by alpha and delta tocopherol. No tocotrienols were detected in the evaluated sample.

Moreover, free fatty alcohols $(20.8 \mathrm{mg} / \mathrm{kg})$, free sterols $(2052.0 \mathrm{mg} / \mathrm{kg})$, waxes $\mathrm{C}_{36}-\mathrm{C}_{46}(26 \mathrm{mg} / \mathrm{kg})$ concentrations were measured to complete the chemical characterisation, using the procedure suggested by Mariani et al. (1999).

Chlorophylls are only present in trace amounts as Pheophitin B + B1 $(0.1 \mathrm{mg} / \mathrm{kg})$ and A $+\mathrm{A} 1 \quad(0.2 \mathrm{mg} / \mathrm{kg})$. The evaluation was carried out using ISO 29841:2009 standard.

\section{Conclusions}

In this short paper, the main chemical properties of Perilla (Perilla frutescens) seed oil, obtained by mechanical pressing of Perilla seeds are reported. The analysis of fatty acid composition allowed to detect a huge amount of (n-3) $\alpha$-linolenic acid (ALA), in concentration of approximately $60 \%$, higher than other ALA rich oils such as linseed and sacha inchi oils, comparable with the one of chia. Perilla oil demonstrated an important sterol and vitamin $\mathrm{E}$ content, while biophenols are in a very low concentration. The analyzed sample showed very low acid and peroxide value and this is the demonstration that, following the proper technological procedures, it is possible to obtain good quality oils, even in presence of high $\alpha$-linolenic acid concentrations. The flavor was evaluated as acceptable, even though this category of oil has not to be used as gourmet oils but as a supplement to cover the low intake of (n-3) fatty acids. The very high content of tocopherols (mainly in the $\gamma$ form) allows a good antioxidative protection of the oil, but we must remember that highly unsaturated oils are very sensitive towards oxidation and must be in every case protected from the action of air and light, even using special containers or inert gases in packaging. Also preparing small packs may encourage a quick consumption once opened. Consuming highly oxidized oils may represent a hazard for human health.

\section{Conflict of interest}

The authors declare that they have no conflicts of interest in relation to this article.

\section{References}

Agenda Gianazza. 1988. Edited by Fratelli Gianazza Div. Legnano, Italy: GOG.

Bondioli P. 2006. Alpha linolenic acid rich oils. Nutritional and technological issues (It.). Riv It Sostanze Grasse 83: 69-73.

Bondioli P, Della Bella L, Rettke P. 2006. Alpha linolenic acid rich oils. Composition of Plukenetia volubilis (Sacha inchi) oil from Peru. Riv It Sostanze Grasse 83: 120-123.

Bondioli P. 2013. Unrefined seed oils obtained by mechanical pressing: a new product for the seed oil industry (It.). La Chimica e l'Industria 87-93. Reprinted by permission in 2019 by Riv. It. Sostanze Grasse 96: 79-83.

Cassiday L. 2017. Chia: superfood or superfad? INFORM 28(1): 6-13.

Li Y, Zhang Y, Sui X, Zhang Y, Feng H, Jiang L. 2014. Ultrasoundassisted aqueous enzymatic extraction of oil from perilla (Perilla frutescens L.) seeds. J Food 12(1): 16-21.

Mariani C, Bellan G, Morchio G, Pellegrino A. 1999. Free and esterified minor components of olive and hazelnut oils: their potential utilization in checking oil blend. Note 1 (It.). Riv It Sostanze Grasse 76: 115-128.

Rodriguez G, Villanueva E, Cortez D, Sanchez E, Aguirre E. 2020. Oxidative stability of chia (Salvia hispanica L.) and sesame (Sesamum indicum L.) blends. J Am Oil Chem Soc 97: 729-735.

Stanley JC. 2009. Confusion on different types of n-3 polyunsaturated fatty acids. Lipid Technol 21(1): 17-18.

Sirilun S, Sivamaruthi BS, Pengkumsri N, Saelee M, Chaiyasut K, Tuntisuwanno N, et al. 2016. Impact of different pre-treatment strategies on the quality of fatty acid composition, tocols content and metabolic syndrome related activities of Perilla frutescens seed oil. J Appl Pharm Sci 6(2): 1-8.

Torri L, Bondioli P, Folegatti L, Rovellini P, Piochi M, Morini G. 2019. Development of Perilla seed oil and extra virgin olive oil 
blends for nutritional, oxidative stability and consumer acceptance improvements. Food Chem 286: 584-591.

Yu HC, Kosuna K, Haga M. 1997. Perilla: the genus Perilla. New York: Taylor \& Francis.
WHO Interim Summary of conclusions \& dietary recommendations on total fat $\&$ fatty acids. 2008. The joint FAO/WHO expert consultation on fats and fatty acids in human nutrition. Geneva (CH): WHO, pp. 1-14.

Cite this article as: Bondioli P, Folegatti L, Rovellini P. 2020. Oils rich in alpha linolenic acid: chemical composition of perilla (Perilla frutescens) seed oil. OCL 27: 67. 